\title{
Luteolin induces mitochondrial apoptosis in HT29 cells by inhibiting the Nrf2/ARE signaling pathway
}

\author{
HUAN YANG $^{1}$, BING-FANG LIU ${ }^{2}$, FU-JIA XIE ${ }^{3}$, WEI-LIN YANG ${ }^{1}$ and NONG CAO ${ }^{1}$ \\ ${ }^{1}$ Department of General Surgery, First Hospital of Lanzhou University; ${ }^{2}$ Department of Nuclear Magnetic Resonance, \\ The Second Clinical Medical College of Lanzhou University, Lanzhou, Gansu 730000; ${ }^{3}$ Department of General Surgery, \\ First Affiliated Hospital of Kunming Medical University, Kunming, Yunnan 650000, P.R. China
}

Received August 22, 2018; Accepted August 30, 2019

DOI: $10.3892 /$ etm.2020.8464

\begin{abstract}
The aim of the current study was to investigate luteolin-induced apoptosis and the molecular mechanisms underlying it in HT29 cells. A 3-(4,5-dimethylthiazol-2-yl)-2,5-diphenyltetrazolium bromide assay was used to assess the cytotoxicity of luteolin on HT29 cells, and a dichloro-dihydro-fluorescein diacetate assay was used to measure cellular levels of reactive oxygen species (ROS). The effects of luteolin on the mitochondrial membrane potential were also evaluated. Bax and Bcl-2 mRNA expression were determined using reverse transcription-quantitative PCR. Additionally, western blot analysis was performed to assess changes in cytochrome $c$ and caspase-3 protein expression. Localization of nuclear factor erythroid 2-related factor 2 (Nrf2) in the nucleus was also assessed using immunofluorescence. Luteolin exhibited cytotoxicity on HT29 cells in a time- and concentration-dependent manner. Additionally, ROS production was indicated to be increased and ROS scavenging was decreased, which resulted in a significant increase in the levels of ROS in the cells. The mitochondrial membrane potential was indicated to decrease following luteolin treatment. At the molecular level, luteolin significantly increased the mRNA expression of Bax and the protein expression of cytochrome $\mathrm{c}$, caspase-3, p47 $7^{\text {phox }}$ and $\mathrm{p} 22^{\text {phox }}$. The results revealed that luteolin decreased $\mathrm{Bcl}-2$ protein expression and inhibited the nuclear localization of $\mathrm{Nrf} 2$. In conclusion, the current study indicated that luteolin inhibited HT29 cell proliferation and induced apoptosis via the mitochondrial pathway.
\end{abstract}

\section{Introduction}

Colon cancer is a common malignant tumor of the digestive tract that can improve with lifestyle and diet modifications (1).

Correspondence to: Professor Nong Cao, Department of General Surgery, First Hospital of Lanzhou University, 1 Dong Gang West Road, Lanzhou, Gansu 730000, P.R. China

E-mail: caonong1955@126.com

Key words: luteolin, mitochondrial apoptosis, HT29 cells, nuclear factor erythroid 2-related factor 2/antioxidant responsive element
Previously, there has been a decline in the incidence of CRC in adults older than 50 years in the United States; however, the number of new cases is expected to increase among young adults aged 20-49 years by 2030 (2). The 5-year survival rate for colon cancer is relatively high, however, the high recurrence rate and metastasis of the tumor to distant organs is the primary cause of mortality in patients with this disease $(3,4)$. In recent years, colon cancer has become one of the main causes of cancer-associated mortality (5). Treatments used for colon cancer include surgery, radio- and chemotherapy. With the development of technology, these traditional methods have undergone a number of improvements $(6,7)$. However, these improvements are insufficient in meeting clinical needs, including prolonging survival, preventing cancer metastasis, and reducing recurrence rates (4). To achieve an increased survival rate and improved treatment efficacy, the development and evaluation of phytochemicals that exhibit anticancer properties is urgently required.

Luteolin (3',4',5,7-tetrahydroxy-flavone) is an important flavonoid that can be found in honeysuckle, chrysanthemum, nepeta and Prunella vulgaris (8). Celery, sweet pepper, Chinese cabbage, cauliflower and Camellia sinensis also contain large quantities of luteolin (9). Luteolin has been revealed to exhibit anti-inflammatory, antioxidative and anticancer properties (9). Luteolin has also been reported to decrease serum glucose and exhibit a number of other pharmacological activities $(8,10,11)$. Studies have demonstrated that luteolin can provide resistance against oncogenic stimulation in vivo and in vitro, inhibit cell proliferation, and induce cell cycle arrest and apoptosis by stimulating or inhibiting intracellular and extracellular signaling pathways $(12,13)$. Furthermore, the efficacy of luteolin in treating colon cancer has been previously reported $(14,15)$. Luteolin has been indicated to induce apoptosis in colon cancer cells by arresting the cell cycle at the $\mathrm{G} 2 / \mathrm{M}$ phase $(11,13)$. Recent research has revealed that the molecular mechanisms underlying the luteolin-induced apoptosis of colon cancer cells is associated with the inhibition of the Wnt/ $\beta$-catenin/glycogen synthase kinase-3 $\beta$ (16) and phosphatidylinositol 3-kinase/Akt signaling pathways (17), reduction of antioxidant capacity (16) and the induction of changes in the ceramide/sphingosine-1-phosphate ratio (18).

A variety of drugs exert an anticancer effect by increasing the level of reactive oxygen species (ROS) and activating the 
mitochondrial apoptosis pathway $(19,20)$. It has been indicated that the nuclear factor erythroid 2-related factor 2 (Nrf2)/antioxidant responsive element (ARE) signaling pathway is an important pathway during the cellular antioxidant response (21). Furthermore, it has been demonstrated that the regulation of antioxidant enzymes and phase II detoxification enzymes via this signaling pathway can result in the scavenging of ROS and other harmful substances (22).

The current study was performed to investigate whether luteolin induces mitochondrial apoptosis in the colon cancer cell line HT29 by inhibiting the Nrf2/ARE signaling pathway.

\section{Materials and methods}

Cells and reagents. HT29 cells were purchased from the Cell Bank of Type Culture Collection of Chinese Academy of Sciences.

Luteolin was purchased from Dalian Meilun Biology Technology Co., Ltd. MTT (cat. no. 298-93-1), DMSO (cat. no. 68-67-5), FBS and high-glucose DMEM were purchased from Beijing Solarbio Science \& Technology Co., Ltd. Dichloro-dihydro-fluorescein diacetate (DCFH-DA, cat. no. d6883) was obtained from Sigma-Aldrich; Merck KGaA. RIPA buffer (cat. no. P0013C), SDS-PAGE gel preparation kit (cat. no. P0012A) and Mitochondrial Membrane Potential Detection kit (cat. no. C2006) were purchased from Beyotime Institute of Biotechnology. RNAiso Plus (cat. no. 9108; Takara Biotechnology Co., Ltd.), the PrimeScript RT Reagent kit (cat. no. rr047a) and TB Green Premix Ex Taq II kit (cat. no. rr8201) were obtained from Takara Bio, Inc., rabbit anti-cytochrome $c$ (cyt C) monoclonal antibody (1:2,500; cat. no. ab133504), rabbit anti-caspase-3 monoclonal antibody (1:500; cat. no. ab197202), rabbit anti-p47 $7^{\text {phox }}$ monoclonal antibody (1:2,500; cat. no. ab181090), rabbit anti-p22 $2^{\text {phox }}$ monoclonal antibody $(1: 2,000$; cat. no. ab191512), rabbit $\beta$-actin antibody (1:1,000; cat. no. bs-0061R), goat anti-rabbit IgG-HRP $(\mathrm{H}+\mathrm{L})$ secondary antibody (1:1,000; cat. no. E030120), rabbit anti-Nrf2 monoclonal antibody (1:250; cat. no. ab62352) and Alexa Fluor ${ }^{\circledR}$ 647-labeled goat anti-rabbit fluorescent secondary antibody (1:500; cat. no. ab150079) was purchased from Abcam. The primers used in the RT-qPCR were as follows: Bax forward, 5'-CATGGAGCTGCAGAGGATGA-3' and reverse, 5'-CTCCCGGAGGAAGTCCAAT-3' (NG_012191; length 318); Bcl-2 forward, 5'-AGGATTGTGGCCTTCTTT GAGT-3' and reverse, 5'-ACTGCTTTAGTGAACCTTTTG CAT-3' (NG_009361; length 335) and $\beta$-actin forward, 5'-CGC GAGAAGATGACCCAGAT-3' and reverse, 5'-GCACTGTGT TGGCGTACAGG-3' (NG_007992; length 550).

MTT assay. Cells in the log growth phase were digested to obtain a single-cell suspension with a density of $1.5 \times 10^{5} \mathrm{cells} / \mathrm{ml}$. Subsequently, $100 \mu \mathrm{l}$ cell suspension cultured in high-glucose DMEM containing 10\% FBS was added to each well of a 96-well plate, after which the plate was incubated for $24 \mathrm{~h}\left(37^{\circ} \mathrm{C}\right.$; $5 \% \mathrm{CO}_{2}$ ). Luteolin was added to the wells at a final concentration of $10,20,40,80$ or $160 \mu \mathrm{M}$, with six parallel wells for each group. $100 \mu \mathrm{l}$ of solvent (0.1\% DMSO) was added to the blank control cells. Cells were treated for 24,48 or $72 \mathrm{~h}$. A total of $20 \mu 1$ MTT solution $(5 \mathrm{mg} / \mathrm{ml})$ was subsequently added to each well, after which the plate was incubated at $37^{\circ} \mathrm{C}$ for an additional $4 \mathrm{~h}$. The supernatant was discarded and the MTT in each well was dissolved in $150 \mu \mathrm{l}$ DMSO. Optical density (OD) was measured at $490 \mathrm{~nm}$ and inhibition rate (IR) was calculated as follows: $\operatorname{IR}(\%)=[\mathrm{OD}($ blank control)-OD(experimental group)]/OD(blank control) x blank. The half-maximal inhibitory concentration $\left(\mathrm{IC}_{50}\right)$ values of luteolin on $\mathrm{HT} 29$ cells were determined by a plotting dose-response curve.

Measurement of intracellular ROS level. A cell suspension containing $5 \times 10^{5}$ cells $/ \mathrm{ml}$ was prepared from HT29 cells in the log growth phase. A total of $5 \times 10^{4}$ cells/well were inoculated into a 6-well plate and cultured overnight. After the cells adhered to the plate, 20 or $40 \mu \mathrm{M}$ luteolin was added, and an equal volume of DMSO was added to the blank control cells. After $48 \mathrm{~h}$, the culture medium (high-glucose DMEM containing $10 \%$ FBS) was aspirated. A total of $10 \mu \mathrm{mol} / 1$ DCFH-DA serum-free medium was then added to the culture. The mixture was lightly agitated until all the cells were covered, followed by incubation at $37^{\circ} \mathrm{C}$ for $20 \mathrm{~min}$. Cells were then rapidly washed three times with serum-free medium to remove DCFH-DA that did not enter the cells. Finally, a total of $1 \times 10^{3}$ cells/field of view were imaged using a fluorescence microscope under x20 magnification. The fluorescence intensity was measured (Image Pro Plus 6.0; Media Cybernetics) to determine the level of intracellular ROS.

Measurement of mitochondrial membrane potential. HT29 cells were treated as aforementioned. After $48 \mathrm{~h}$ of treatment with luteolin, the culture medium was aspirated and the cells were washed once with PBS. A total of $1 \mathrm{ml}$ culture medium (high-glucose DMEM containing 10\% FBS) and $1 \mathrm{ml} \mathrm{JC}-1$ stain working solution were successively added to the suspension, which was then mixed thoroughly. Cells were incubated at $37^{\circ} \mathrm{C}$ for $20 \mathrm{~min}$ and digested using trypsin. A multifunctional spectrophotometer was used to measure absorbance at excitation and emission wavelengths of 525 and $590 \mathrm{~nm}$, respectively.

Immunofluorescence. HT29 cells in the log growth phase were digested with trypsin to obtain a single-cell suspension containing $1 \times 10^{4}$ cells $/ \mathrm{ml}$. A total of $2 \mathrm{ml}$ suspension was subsequently placed in each well of a six-well plate with coverslips at the bottom of each well. After adhesion, cells were treated for $48 \mathrm{~h}$ with 20 or $40 \mu \mathrm{M}$ luteolin. Cells were subsequently fixed with $4 \%$ paraformaldehyde at $37^{\circ} \mathrm{C}$ for $30 \mathrm{~min}$, permeabilized with $0.3 \%$ Triton X-100 for $15 \mathrm{~min}$ at room temperature, blocked in PBS containing 1\% BSA for $1 \mathrm{~h}$ at $37^{\circ} \mathrm{C}$, incubated with primary antibodies against $\mathrm{Nrf} 2$ (1:250) overnight at $4^{\circ} \mathrm{C}$, washed, treated with Alexa Fluor ${ }^{\circledR}$ 647-labeled goat anti-rabbit fluorescent secondary antibody (1:500) for $30 \mathrm{~min}$ at $37^{\circ} \mathrm{C}$, washed and imaged using a fluorescence microscope under x200 magnification.

$R T-q P C R$. HT29 cells in the log growth phase were treated for $48 \mathrm{~h}$ with 20 or $40 \mu \mathrm{M}$ luteolin or with an equal volume of vehicle as the blank control. A total of $1.5 \mathrm{ml}$ TRIzol reagent was subsequently added to the suspension, which was then triturated on ice, left to stand for $5 \mathrm{~min}$ and centrifuged at $13,000 \mathrm{x} \mathrm{g}$ for $5 \mathrm{~min}$ at $4^{\circ} \mathrm{C}$. Supernatant was collected and $200 \mu \mathrm{l}$ chloroform was added. The mixture was left to stand for $5 \mathrm{~min}$ and then centrifuged at $13,000 \mathrm{x}$ g for $10 \mathrm{~min}$ at $4^{\circ} \mathrm{C}$. 
The supernatant was collected and $400 \mu \mathrm{l}$ isopropyl alcohol was added. The mixture was left to stand and subsequently centrifuged at $13,000 \mathrm{xg}$ for $10 \mathrm{~min}$ at $4^{\circ} \mathrm{C}$. The supernatant was discarded and the precipitate obtained was washed with $75 \%$ ethanol. The mixture was then centrifuged to remove the ethanol and the supernatant was discarded. The precipitate was dried using super-clean bench at room temperature for $2 \mathrm{~min}$, and dissolved in $20 \mu \mathrm{l}$ nuclease-free water at room temperature. Genomic DNA removal and RT were performed using a reaction kit with the following thermocycling conditions: $25^{\circ} \mathrm{C}$ for $5 \mathrm{~min}, 42^{\circ} \mathrm{C}$ for $30 \mathrm{~min}$ and $85^{\circ} \mathrm{C}$ for $5 \mathrm{~min}$. During qPCR, denaturation was performed at $95^{\circ} \mathrm{C}$ for $10 \mathrm{~min}$ and amplification was performed at $95^{\circ} \mathrm{C}$ for $15 \mathrm{sec}, 60^{\circ} \mathrm{C}$ for $15 \mathrm{sec}$ and $72^{\circ} \mathrm{C}$ for $30 \mathrm{sec}$ for 40 cycles. Data were analyzed using the $2^{-\Delta \Delta \mathrm{Cq}}$ method (23) and normalized to the internal reference gene $\beta$-actin.

Western blot analysis. HT29 cells in the log growth phase were treated for $48 \mathrm{~h}$ with 20 or $40 \mu \mathrm{m}$ luteolin or with an equal volume of vehicle that was used as the blank control. RIPA buffer was added to the cells on ice and cells were ground. The lysate was kept at $4^{\circ} \mathrm{C}$ for $30 \mathrm{~min}$ and subsequently centrifuged at $13,000 \mathrm{x}$ g for $10 \mathrm{~min}$ at $4^{\circ} \mathrm{C}$. Supernatant was collected and a BCA assay kit was used to measure protein concentration. Afterwards, $4 \mathrm{X}$ loading buffer was added the remaining supernatant, and the $30 \mu \mathrm{g}$ of protein sample was denatured and added to a $4 \%$ stacking $/ 10 \%$ resolving gel. Samples were then blotted onto a PVDF membrane, blocked with 5\% skim milk in TBS containing $0.05 \%$ Tween-20 (TBS-T) for $1 \mathrm{~h}$ at room temperature, incubated with primary antibodies against cyt $C(1: 2,500)$, caspase-3 (1:500), p4 $7^{\text {phox }}(1: 2,500), \mathrm{p} 22^{\text {phox }}$ $(1: 2,000)$ and $\beta$-actin $(1: 1,000)$ overnight at $4^{\circ} \mathrm{C}$ and incubated with secondary antibodies goat anti-rabbit IgG-HRP $(\mathrm{H}+\mathrm{L})$ $(1: 1,000)$ for $1 \mathrm{~h}$ at room temperature. Enhanced chemiluminescence, X-ray development, gel imaging (Bio-Rad ChemiDoc XRS+ 170-8625; Bio-Rad Laboratories, Inc.) and image analysis (ImageJ 1.8; National Institutes of Health) were subsequently performed.

Statistical analysis. SPSS (version 21.0; IBM Corp.) was used for data analysis. One-way ANOVA was used for comparison among multiple groups with LSD post-hoc tests. $\mathrm{P}<0.05$ was considered to indicate a statistically significant result. Data are presented as the mean \pm SEM.

\section{Results}

The cytotoxicity of luteolin on HT29 cells. Fig. 1 indicated that for each exposure period, as the concentration of luteolin was increased, the cytotoxicity of luteolin on HT29 cell gradually increased. The half-maximal inhibitory concentration $\left(\mathrm{IC}_{50}\right)$ values of luteolin were calculated as $69.66 \pm 3.42,28.94 \pm 2.37$ and $22.30 \pm 3.05 \mu \mathrm{M}$ when cells were treated for 24,48 and $72 \mathrm{~h}$, respectively. Furthermore, for each concentration, the cytotoxicity of luteolin gradually increased for the different incubation periods.

Effect of luteolin in HT29 cells. Fig. 2 demonstrated that as the luteolin concentration was increased, the ROS level in the HT29 cells increased.

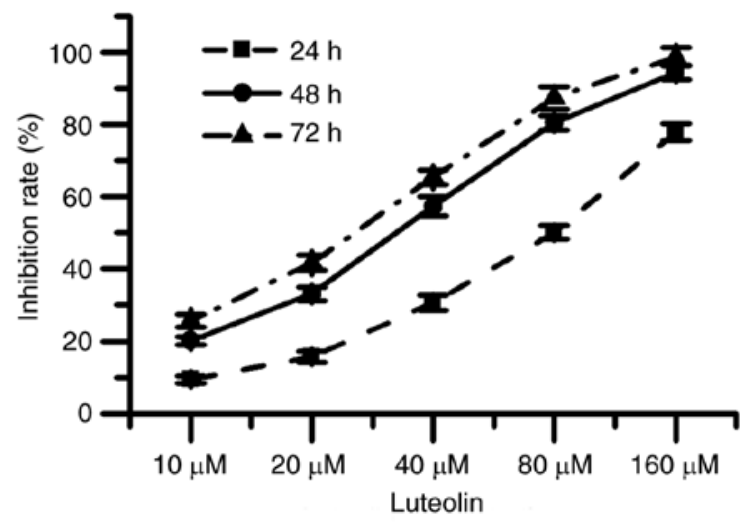

Figure 1. MTT assay was used to assess the effects of luteolin on HT29 cell proliferation. Data are expressed as the mean \pm SEM.

Fig. 3 indicated that as the luteolin concentration was increased, the mitochondrial membrane potential of HT29 cells decreased. The mitochondrial membrane potential was indicated to be significantly lower in cells treated with 20 and $40 \mu \mathrm{M}$ luteolin compared with blank control cells.

Fig. 4 demonstrated that as the luteolin concentration was increased, mRNA expression of Bax increased and of Bcl-2 decreased. These results indicated that Bcl-2 can prevent multiple signaling pathways from blocking cell apoptosis and prolonging cell survival. Bax is a mitochondrial membrane protein that can promote or mediate apoptosis $(24,25)$. Additionally, the mRNA expression of Bax and Bcl-2 were significantly different in the cells treated with 20 and $40 \mu \mathrm{M}$ compared with the respective blank control cells.

The results indicated that as the luteolin concentration was increased, the protein expression of cyt $\mathrm{C}$ and caspase-3 in the HT29 cells gradually increased (Fig. 5). Additionally, $\mathrm{p} 47^{\text {phox }}$ and $\mathrm{p} 22^{\text {phox }}$ protein levels in the cells gradually increased (Fig. 6).

Fig. 7A and $\mathrm{B}$ demonstrated that as the luteolin concentration increased, nuclear Nrf2 localization in HT29 cells decreased.

\section{Discussion}

Dysregulated cell proliferation is a characteristic of a large number of cancer types (26). Therefore, the induction of apoptosis is a beneficial characteristic for anticancer drugs to exhibit. Previous studies have demonstrated that resveratrol, matrine, quercetin and a number of other phytochemicals induce apoptosis and inhibit the proliferation of liver, stomach, oral, skin and colon cancers (27-29). Luteolin is a flavonoid that has been indicated to arrest the cell cycle and induce apoptosis in a variety of different cancer types $(13,14,27)$. In the present study, the results of the MTT assay demonstrated that luteolin exhibited cytotoxicity on HT29 cell in a concentration- and time-dependent manner, which is consistent with the results of other studies $(17,30)$.

Signaling networks, including pathways associated with cell proliferation, are modified in a number of cancer types, which makes cells unable to regulate their properties (31). Dysregulated proliferation is the basis of the development and 


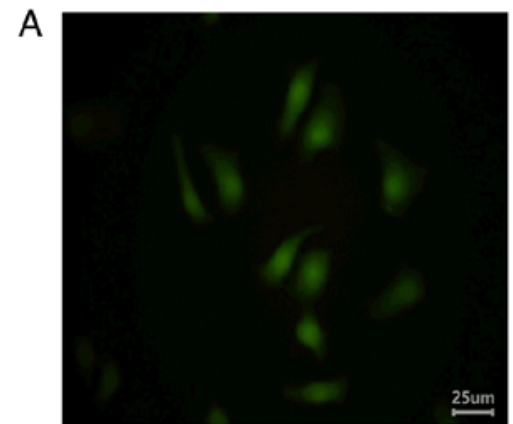

Control

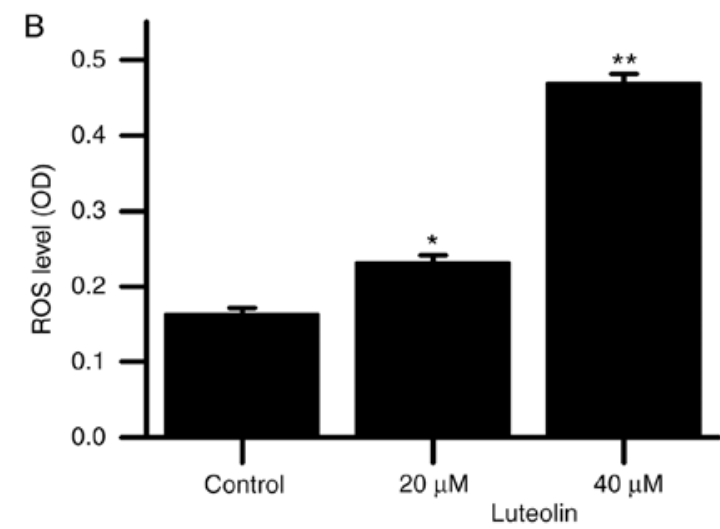

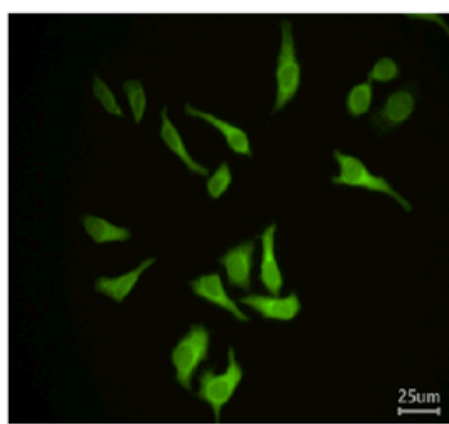

$20 \mu \mathrm{M}$ 25 un

Luteolin

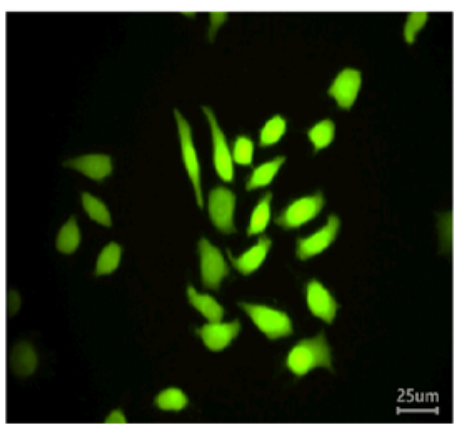

$40 \mu \mathrm{M}$

Figure 2. Effects of luteolin on ROS levels in HT29 cells. (A) Observation of ROS expression in HT29 cells by fluorescence microscopy. (B) ROS levels in HT29 cells. Data are expressed as the mean \pm SEM. ${ }^{*} \mathrm{P}<0.05$ and ${ }^{* *} \mathrm{P}<0.1$ vs. control. ROS, reactive oxygen species.

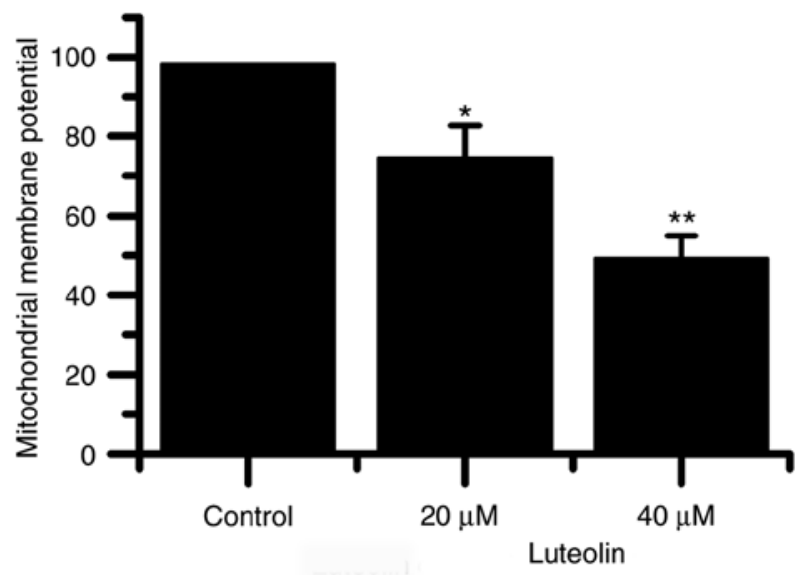

Figure 3. Effect of luteolin on mitochondrial membrane potential in HT29 cells. Data evaluation for the mitochondrial membrane potential was based on JC-1 staining results. Data are expressed as the mean \pm SEM. ${ }^{*} \mathrm{P}<0.05$ and ${ }^{* *} \mathrm{P}<0.01$ vs. control.

progression of cancer, and it has been revealed that apoptosis and cell cycle signaling pathways, and proteins associated with these processes, are directly associated with cancer cell proliferation $(32,33)$. Apoptosis may occur via the mitochondrial or death receptor pathway (34). The majority of tumors avoid intrinsic and extrinsic apoptosis by modifying the expression or structure of proteins associated with apoptosis, which causes cancer cells to exhibit higher error tolerance and resistance (33). Therefore, the induction of apoptosis is an important anticancer mechanism that can be identified in chemotherapeutic agents.
During the initiation of apoptosis, an abnormal increase in ROS occurs, which is an important stimulus for mitochondrial apoptosis (35). It has been demonstrated that a number of drugs induce apoptosis of cancer cells by increasing ROS levels $(36,37)$. In the present study, it was indicated that luteolin induced an increase in ROS level in HT29 cells. Changes in cellular ROS levels are directly associated with changes in mitochondrial function, with abnormalities in the electron permeability of the mitochondrial membrane leading to significant changes in cellular ROS levels (38). Additionally, mitochondria are most vulnerable to ROS attack $(39,40)$. In the present study, luteolin decreased the mitochondrial membrane potential in HT29 cells. Therefore, the luteolin-induced increase in mitochondrial membrane permeability may result in increased ROS levels in HT29 cells. However, the current study did not use normal human colon cells as a control, which may lead to the inability of the present study to directly determine whether luteolin induces increased ROS in normal colon cells, which would allow for the specificity and side effects of luteolin to be assessed accurately. Therefore, future studies will aim to determine the effect of luteolin on the levels of ROS and apoptosis in normal human colon cells.

Changes in mitochondrial membrane permeability are determined by the relative levels of Bcl-2 and Bax. In the mitochondrial apoptotic pathway, Bax promotes apoptosis by damaging mitochondrial membrane integrity, whereas Bcl-2 inhibits apoptosis by maintaining the integrity of the mitochondrial membrane (41). The results of the present study indicated that luteolin increased Bax mRNA expression and downregulated Bcl-2 mRNA expression. 

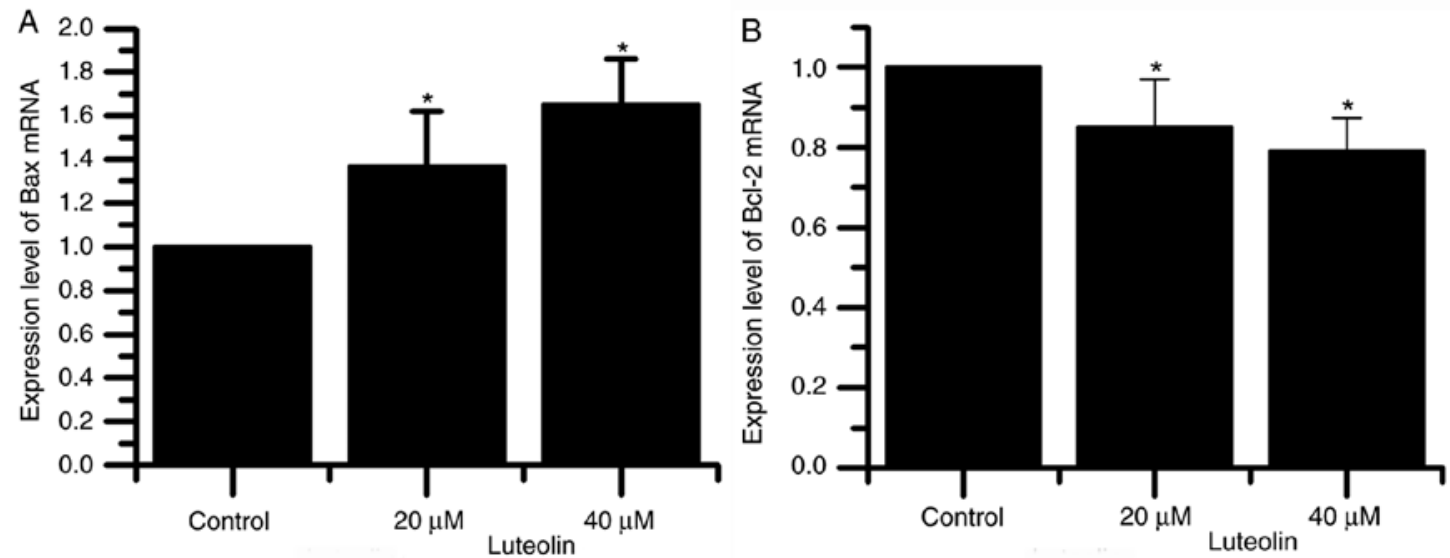

Figure 4. Reverse transcription-quantitative PCR analysis of Bax and Bcl-2 genes in HT29 cells treated with luteolin. (A) mRNA expression levels of Bax after luteolin treatment for 48 h. (B) mRNA expression levela of $B c l-2$ after luteolin treatment for 48 h. Data are expressed as the mean \pm SEM. * $\mathrm{P}<0.05$ vs. control.

A

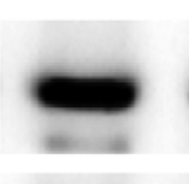

Caspase-3
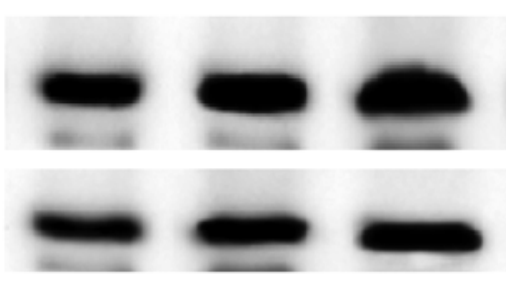

$\beta$-actin

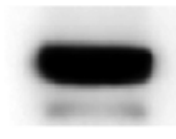

Control

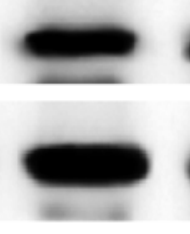

$20 \mu \mathrm{M}$ Luteolin

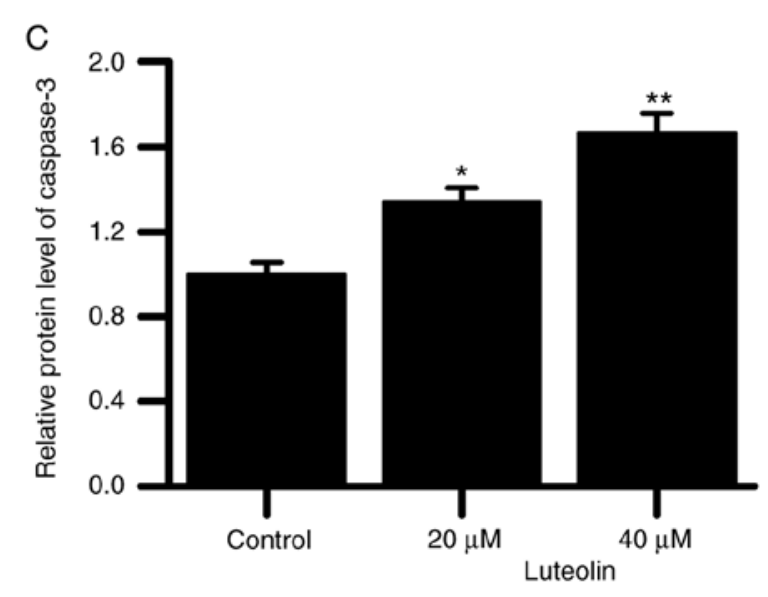

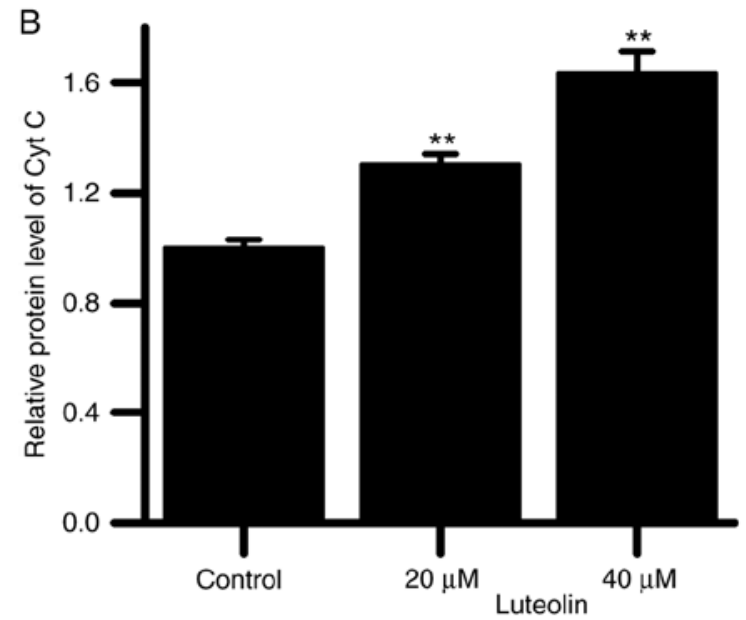

Figure 5. Western blot analysis of cyt $\mathrm{C}$ and caspase-3 protein expression in HT29 cells treated with luteolin. (A) Protein expression levels of cyt C and caspase- 3 were detected after luteolin treatment for $48 \mathrm{~h}$ by western blotting. (B) Protein expression levels of cyt $\mathrm{C}$ after luteolin treatment for $48 \mathrm{~h}$. (C) Protein expression levels of caspase-3 after luteolin treatment for $48 \mathrm{~h}$. Data are expressed as the mean $\pm \mathrm{SEM}$. ${ }^{*} \mathrm{P}<0.05$ and ${ }^{* *} \mathrm{P}<0.01$ vs. control.cyt $\mathrm{C}$, cytochrome $c$.

As mitochondrial membrane permeability changes, the movement of cyt $\mathrm{C}$ from the mitochondria to the cytoplasm is important in the initiation of the caspase apoptosis cascade (42). The results of the current study indicated that luteolin increased the expression of cyt $\mathrm{C}$ and caspase- 3 proteins in HT29 cells, and the increase of cyt C and caspase-3 protein levels make HT29 cells more sensitive to the intrinsic apoptotic pathway (43). The results of the current study revealed that luteolin induced apoptosis of
HT29 cells by stimulating the mitochondrial apoptotic pathway. However, the present study only demonstrated that luteolin induced mitochondrial apoptosis in HT29 cells through the detection of mitochondrial permeability and mitochondrial apoptosis-associated proteins and did not identify the modification of mitochondria. The modification of mitochondria can directly reflect the occurrence of mitochondrial apoptosis (44). Therefore, future studies may assess the modification of mitochondria. 

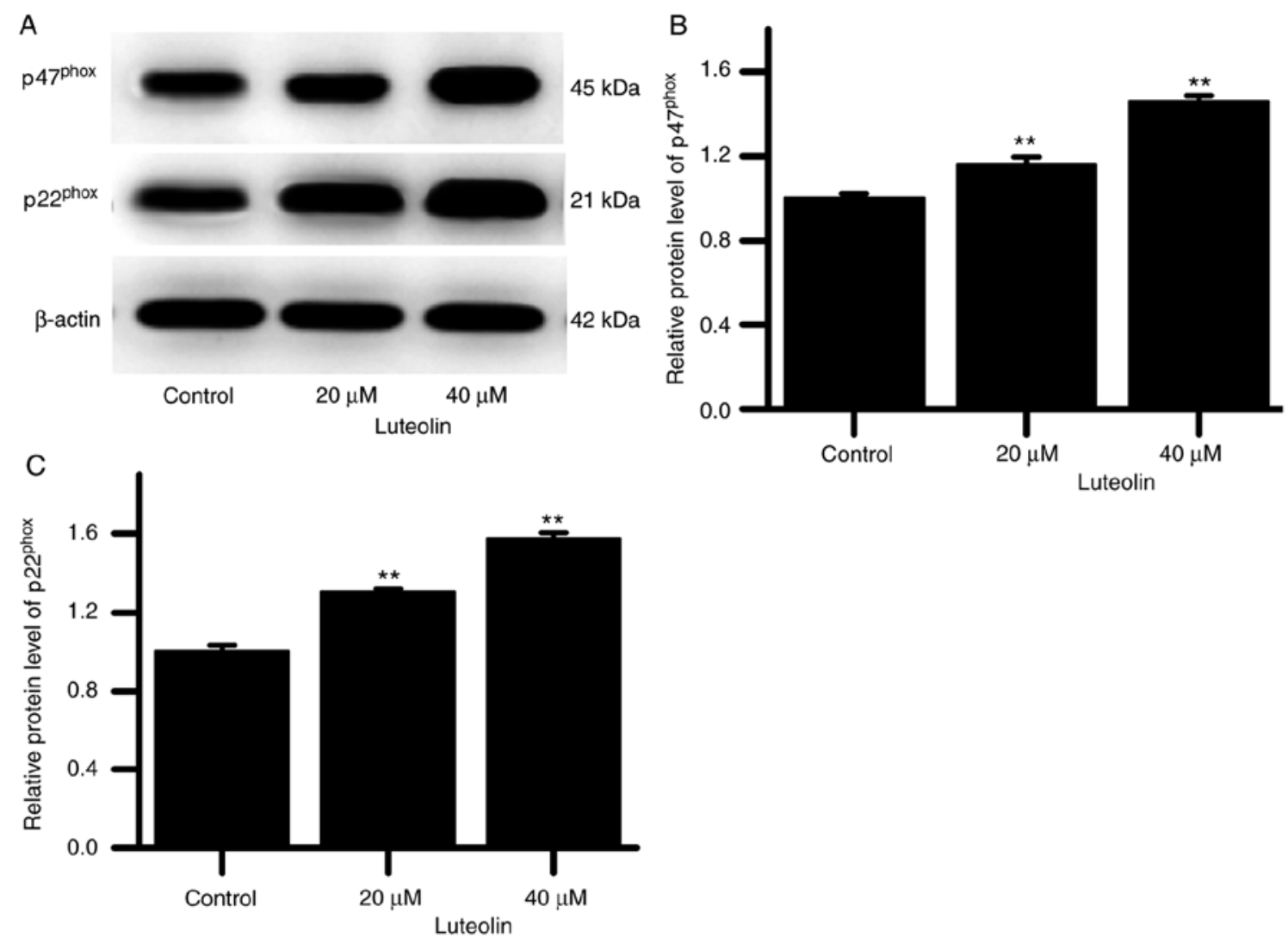

Figure 6. Western blot analysis of the p47 phox , and p22 $2^{\text {phox }}$ protein expression in HT29 cells treated with luteolin. (A) Protein expression levels of p47 ${ }^{\text {phox }}$ and p2 $2^{\text {phox }}$ were detected after luteolin treatment for $48 \mathrm{~h}$ by western blotting. (B) Protein expression levels of p47 ${ }^{\text {phox }}$ after luteolin treatment for $48 \mathrm{~h}$. (C) Protein expression levels of $\mathrm{p} 22^{\mathrm{phox}}$ after luteolin treatment for $48 \mathrm{~h}$. Data are expressed as the mean $\pm \mathrm{SEM} .{ }^{* *} \mathrm{P}<0.01 \mathrm{vs}$. control.

Luteolin can increase ROS levels in HT29 cells. Increased endogenous cellular ROS levels are associated with ROS production and clearance pathways (45). NADPH oxidase (NOX) is a membrane protein that is widely distributed in tissues and organs (46). NOX reduces oxygen molecules in the body to superoxide anions through NADPH-dependent electron transfer (47). Furthermore, NOX has been indicated to be responsible for ROS generation in the body (48). NOX exhibits little catalytic activity and binds to a number of regulatory subunits to form a stable complex before it can exert any catalytic activity (49), including $\mathrm{p} 47^{\text {phox }}$ and $\mathrm{p} 22^{\text {phox }}$, which are important cofactors that are required for the stability of NOX. In the present study, luteolin was revealed to promote $\mathrm{p} 47^{\text {phox }}$ and $\mathrm{p} 22^{\text {phox }}$ expression in HT29 cells. This result suggested that luteolin may increase ROS levels in HT29 cells by increasing NOX stability. Furthermore, cellular ROS levels determine the activity of the antioxidant system (50). Recent studies have demonstrated that the Nrf2/ARE signaling pathway is an essential pathway during antioxidant response in cells (51). The regulation of antioxidant enzymes and phase II detoxification enzymes by this signaling pathway can result in the ROS scavenging, which can result in a detoxifying and neutralizing effect (22).

The results of the present study also indicated that luteolin inhibited Nrf2 activation, blocked nuclear localization of Nrf2 and inhibited the expression of antioxidant enzymes. Therefore, it was revealed that luteolin prevented Nrf2 activation and promoted abnormal ROS level increases in HT29 cells by modulating the expression of $\mathrm{p} 47^{\text {phox }}$ and $\mathrm{p} 22^{\text {phox }}$. ROS levels in cancer cells are high compared with normal cells. Furthermore, in cancer cells that are adapted to high ROS levels, further increases in ROS levels can promote cell apoptosis.

However, other studies have demonstrated that luteolin can induce the demethylation of the Nrf2 gene promoter region, upregulate the Nrf2 gene expression, activate the Nrf2/ARE pathway, increase the antioxidant capacity, inhibit the transformation and promote apoptosis of colon cancer cells $(52,53)$, which is not supported by the results of the present study. In the current study, it was speculated that the antioxidant capacity served a different role at different stages of cancer development. The increase of antioxidant capacity reduces the level of ROS, protects cells from DNA damage caused by oxidative stress, and inhibits further transformation of tumors. Conversely, the improvement of antioxidant capacity exhibits an increase drug resistance and oxidation resistance ability to tumor cells, promoting the development of tumors.

In conclusion, luteolin induced apoptosis in HT29 cells by promoting ROS production and inhibiting ROS scavenging through stimulating the mitochondrial apoptotic pathway. However, the current study did not identify a useful luteolin inhibitor, and the effects of luteolin on the proliferation, apoptosis and ROS production of HT29 cells could not be fully identified. Future studies will aim to identify a suitable luteolin inhibitor for use in subsequent research.

\section{Acknowledgements}

Not applicable. 

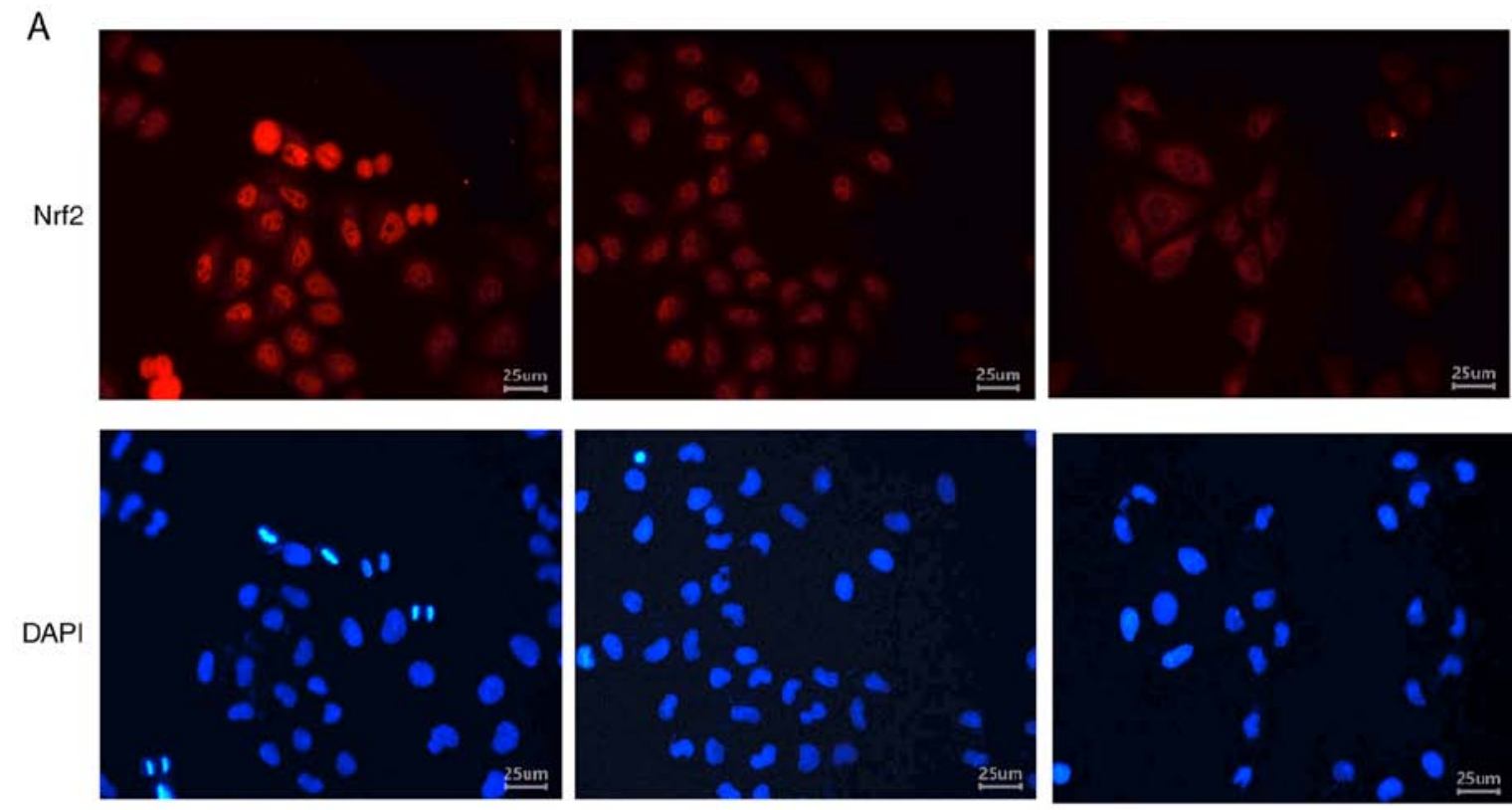

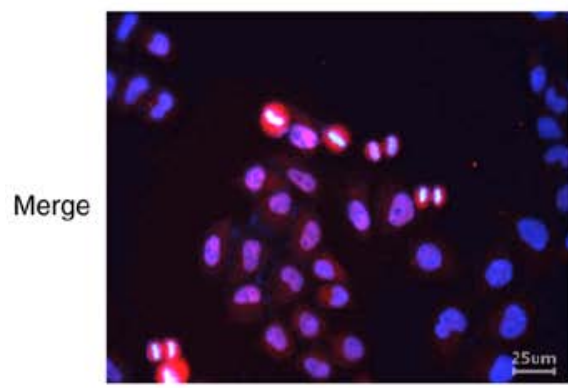

Control

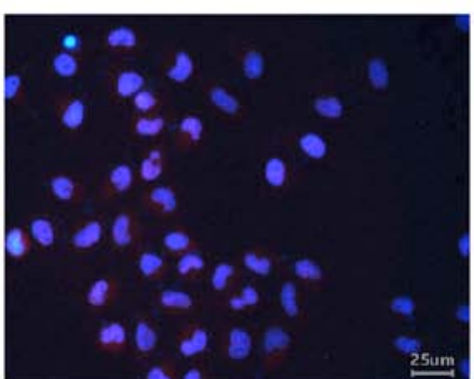

$20 \mu \mathrm{M}$

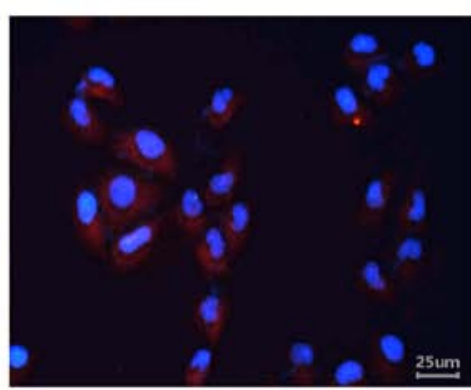

$40 \mu \mathrm{M}$

Luteolin

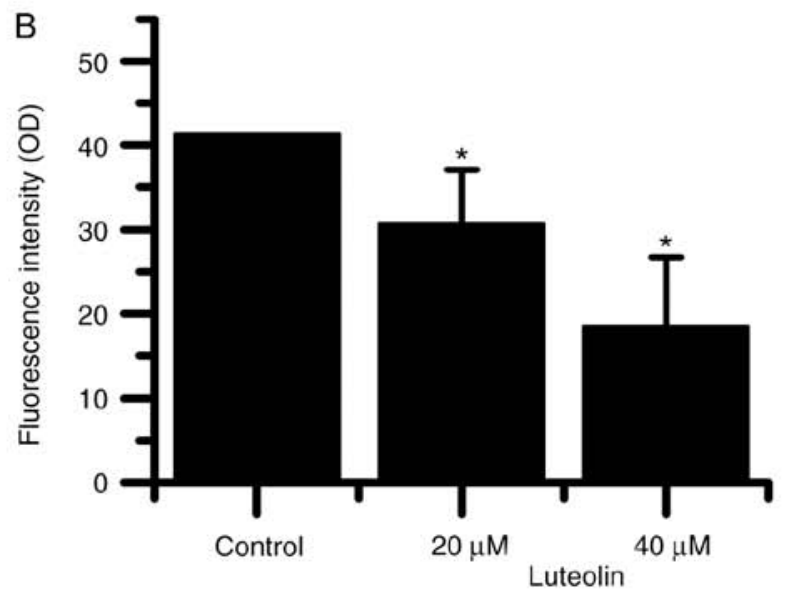

Figure 7. Immunofluorescence analysis of Nrf2 localization in HT29 cells treated with luteolin. (A) Expression of Nrf2 was determined by immunohistochemistry staining. (B) Fluorescence intensity of Nrf2. Data are expressed as the mean \pm SEM. "P $<0.05$ vs. control. Nrf2, nuclear factor erythroid 2 -related factor 2 .

\section{Funding}

The current work was supported by the Scientific Research Project of Gansu Health Industry (grant no. GSWSKY2017-15).

\section{Availability of data and materials}

The datasets used and/or analyzed during the current study are available from the corresponding author on reasonable request.

\section{Authors' contributions}

FJX and NC designed the research. FJX performed the MTT assay, measurement of intracellular ROS levels and measurement of mitochondrial membrane potential. WLY performed immunofluorescence experiments, RT-qPCR, and western blot analysis. HY and BFL analyzed and interpreted the data and finalized the manuscript. All authors read and approved the final version of the manuscript. 


\section{Ethics approval and consent to participate}

Not applicable.

\section{Patient consent for publication}

Not applicable.

\section{Competing interests}

The authors declare that they have no competing interests.

\section{References}

1. Siegel RL, Miller KD and JEMAL A: Cancer statistics, 2019. Ca Cancer J Clin 69: 7-34, 2019.

2. Bailey CE, Hu CY, You YN, Bednarski BK, RodriguezBigas MA, Skibber JM, Cantor SB and Chang GJ: Increasing disparities in the age-related incidences of colon and rectal cancers in the united states, 1975-2010. JAMA Surg 150: 17-22, 2015.

3. Reddy BS: Metabolic epidemiology of colon cancer. Oncology 1991: 88-98, 2015.

4. Aran V, Victorino AP, Thuler LC and Ferreira CG: Colorectal cancer: Epidemiology, disease mechanisms and interventions to reduce onset and mortality. Clin Colorectal Cancer 15: 195-203, 2016.

5. Cunningham D, Atkin W, Lenz HJ, Lynch HT, Minsky B, Nordlinger B and Starling N: Colorectal cancer. Lancet 375 : 1030-1047, 2010.

6. Chang HF and Yang LL: Gamma-mangostin, a micronutrient of mangosteen fruit, induces apoptosis in human colon cancer cells. Molecules 17: 8010-8021, 2012.

7. Scagliarini L, Anania G, Marino S, Marchitelli I and Resta G: Treatment of colorectal cancer: Multidisciplinay approach. Eur J Surg Oncol 44: 555, 2018

8. Lin Y, Shi R, Wang X and Shen HM: Luteolin, a flavonoid with potential for cancer prevention and therapy. Current Cancer Drug Targets 8: 634-646, 2008.

9. Lopez-Lazaro M: Distribution and biological activities of the flavonoid luteolin. Mini Rev Med Chem 9: 31-59, 2009.

10. Xu T, Li D and Jiang D: Targeting cell signaling and apoptotic pathways by luteolin: Cardioprotective role in rat cardiomyocytes following ischemia/reperfusion. Nutrients 4: 2008-2019, 2012.

11. Lim DY, Jeong Y, Tyner AL and Park JH: Induction of cell cycle arrest and apoptosis in HT-29 human colon cancer cells by the dietary compound luteolin. Am J Physiol Gastrointest Liver Physiol 292: G66-G75, 2007.

12. Wu G, Li J, Yue J, Zhang S and Yunusi K: Liposome encapsulated luteolin showed enhanced antitumor efficacy to colorectal carcinoma. Mol Med Rep 17: 2456-2464, 2018.

13. Chen Z, Zhang B, Gao F and Shi R: Modulation of $\mathrm{G}_{2} / \mathrm{M}$ cell cycle arrest and apoptosis by luteolin in human colon cancer cells and xenografts. Oncol Lett 15: 1559-1565, 2018.

14. Meng X, Zhong WQ and Zhang XR: Luteolin inhibits the colon cancer HT-29 cell proliferation,migration and epithelial-mesenchymal transition: An experimental study. J Hainan Med University 23: 5-8, 2017.

15. Chulenbayeva LE, Shaiken TE and Opekun AR: Sa1967 The effect of flavonoids luteolin and quercetin upon colon cancer cells in vitro; 'So What's in Your Fiber'? Gastroenterology 148: S-370, 2015.

16. Pandurangan AK, Dharmalingam P, Sadagopan SK, Ramar M, Munusamy A and Ganapasam S: Luteolin induces growth arrest in colon cancer cells through involvement of Wnt/ $\beta$-catenin/GSK-3 $\beta$ signaling. J Environ Pathol Toxicol Oncol 32: 131-139, 2013.

17. Lim DY, Cho HJ, Kim J, Nho CW, Lee KW and Park JH: Luteolin decreases IGF-II production and downregulates insulin-like growth factor-I receptor signaling in HT-29 human colon cancer cells. BMC Gastroenterol 12: 9, 2012

18. Abdelhadi L, Vito CD, Giussani P, Viani P and Riboni L: Luteolin induces an alteration of the Ceramide/Sphingosine-1-phosphate ratio leading to apoptosis in human colon cancer cells. 2013.

19. Molavian HR, Goldman A, Phipps CJ, Kohandel M, Wouters BG Sengupta S and Sivaloganathan S: Drug-induced reactive oxygen species (ROS) rely on cell membrane properties to exert anticancer effects. Sci Rep 6: 27439, 2016.
20. Chen M,Zhou B,Zhong P, Rajamanickam V, Dai X, Karvannan K, Zhou H, Zhang X and Liang G: Increased intracellular reactive oxygen species mediates the anti-cancer effects of WZ35 via activating mitochondrial apoptosis pathway in prostate cancer cells. Prostate 77: 489-504, 2016.

21. Kobayashi M and Yamamoto M: Molecular mechanisms activating the Nrf2-Keap1 pathway of antioxidant gene regulation. Antioxid Redox Signal 7: 385-394, 2005.

22. Kundu JK and Surh Y: Nrf2-Keap1 signaling as a potential target for chemoprevention of inflammation-associated carcinogenesis. Pharm Res 27: 999-1013, 2010.

23. Livak KJ and Schmittgen TD: Analysis of relative gene expression data using real-time quantitative PCR and the 2(-Delta Delta C(T)) method. Methods 25: 402-408, 2001.

24. Lee MH, Hong SH, Park C, Kim GY, Leem SH, Choi SH, Keum YS, Hyun JW, Kwon TK, Hong SH and Choi YH: Hwang-Heuk-San induces apoptosis in HCT116 human colorectal cancer cells through the ROS-mediated activation of caspases and the inactivation of the PI3K/Akt signaling pathway. Oncol Rep 36: 205-214, 2016.

25. Hoshyar R, Bathaie SZ and Sadeghizadeh M: Crocin triggers the apoptosis through increasing the $\mathrm{Bax} / \mathrm{Bcl}-2$ ratio and caspase activation in human gastric adenocarcinoma, AGS, cells. DNA Cell Biol 32: 50-57, 2013

26. Wood PA, Du-Quiton J, You S and Hrushesky WJ: Circadian clock coordinates cancer cell cycle progression, thymidylate synthase, and 5-fluorouracil therapeutic index. Mol Cancer Ther 5: 2023-2033, 2006.

27. Sun Y, Liu P and Chen J: Traditional Chinese Medicine constitution analysis as predictors for Breast Cancer: A cross-sectional and case control study. Langmuir 12: 4404-4410, 2015.

28. Parekh HS, Liu G and Wei MQ: A new dawn for the use of traditional Chinese medicine in cancer therapy. Mol Cancer 8: 21, 2009.

29. Konkimalla VB and Efferth T: Anti-cancer natural product library from Traditional Chinese medicine. Comb Chem High Throughput Screen 11: 7-15, 2008.

30. Kang KA, Piao MJ, Ryu YS, Hyun YJ, Park JE, Shilnikova K, Zhen AX, Kang HK, Koh YS, Jeong YJ and Hyun JW: Luteolin induces apoptotic cell death via antioxidant activity in human colon cancer cells. Int J Oncol 51: 1169-1178, 2017.

31. Xuemin C, Yi L, Wunier, et al: The diverse roles of small Rho GTPases in cancer cell biology. Chinese J Cell Biol, 2015.

32. Xu Y, So C, Lam HM, Fung MC and Tsang SY: Apoptosis reversal promotes cancer stem cell-like cell formation. Neoplasia 20: 295-303, 2018

33. Lowe SW and Lin AW: Apoptosis in cancer. Carcinogenesis 21: 485-495, 2000.

34. Dobrzycka B, Terlikowski SJ, Bernaczyk PS, Garbowicz M, Niklinski J, Chyczewski L and Kulikowski M: Prognostic significance of Smac/DIABLO in endometrioid endometrial cancer. Folia Histochem Cytobiol 48: 678-681, 2010.

35. Zhao Y, Qu T, Wang P, Li X, Qiang J, Xia Z, Duan H, Huang J and Zhu L: Unravelling the relationship between macroautophagy and mitochondrial ROS in cancer therapy. Apoptosis 21: 517-531, 2016.

36. Liu Y, Yang B, Zhang L, Cong X, Liu Z, Hu Y, Zhang J and $\mathrm{Hu} \mathrm{H}$ : Ginkgolic acid induces interplay between apoptosis and autophagy regulated by ROS generation in colon cancer. Biochem Biophys Res Commun 498: 246-253, 2018.

37. Pavithra PS, Mehta A and Verma RS: Aromadendrene oxide 2 , induces apoptosis in skin epidermoid cancer cells through ROS mediated mitochondrial pathway. Life Sci 197: 19-29, 2018.

38. Babayev E, Wang T, Szigeti-buck K, Lowther K, Taylor HS, Horvath T and Seli E: Reproductive aging is associated with changes in oocyte mitochondrial dynamics, function, and mtDNA quantity. Maturitas 93: 121-130, 2016.

39. Zorov DB, Juhaszova M and Sollott SJ: Mitochondrial reactive oxygen species (ROS) and ROS-induced ROS release. Physiol Rev 94: 909-950, 2014.

40. Cho HD, Lee JH, Moon KD, Park KH, Lee MK and Seo KI: Auriculasin-induced ROS causes prostate cancer cell death via induction of apoptosis. Food Chem Toxicol 111: 660-669, 2017.

41. Opferman JT and Kothari A: Anti-apoptotic BCL-2 family members in development. Cell Death Differ 25: 37-45, 2018.

42. Heidelberg SB: Mitochondria Apoptosis Pathway (M). Springer Berlin Heidelberg, 2008.

43. Huang X, Lu Q, Shen N and Wang Y: Inhibitory effects of Alkaline S. Chinenis polysaccharides on proliferation and invasion abilities of colon cancer HT-29 cells in vitro. J Jilin University Medicine Edition 41: 287-290, 2015 
44. Jeong DW, Kim TS, Cho IT and Kim IY: Modification of glycolysis affects cell sensitivity to apoptosis induced by oxidative stress and mediated by mitochondria. Biochem Biophys Res Commun 313: 984-991, 2004.

45. Rowe LA, Degtyareva N and Doetsch PW: DNA damage-induced reactive oxygen species (ROS) stress response in Saccharomyces cerevisiae 45: 1167-1177, 2008 .

46. Nauseef WM: Nox enzymes in immune cells. Semin Immunopathol 30: 195-208, 2008.

47. Nauseef WM: Assembly of the phagocyte NADPH oxidase. Histochem Cell Biol 122: 277-291, 2004.

48. Spencer NY and Engelhardt JF: The basic biology of redoxosomes in cytokine-mediated signal transduction and implications for disease-specific therapies. Biochemistry 53: 1551-1564, 2014.

49. Brandes RP, Weissmann N and Schröder K: Nox family NADPH oxidases: Molecular mechanisms of activation. Free Radic Biol Med 76: 208-226, 2014.

50. Kang SW, Lee S and Lee EK: ROS and energy metabolism in cancer cells: Alliance for fast growth. Arch Pharm Res 38 $338-345,2015$
51. Cao LJ, Gong H, Yan M, Li HD and Sun L: Research progress on Nrf2-ARE signaling pathway involved in liver disease pathological mechanism. Chinese Pharmacological Bulletin 31: 1057-1061, 2015.

52. Kang KA, Piao MJ, Hyun YJ, Zhen AX, Cho SJ, Ahn MJ, Yi JM and Hyun JW: Luteolin promotes apoptotic cell death via upregulation of Nrf2 expression by DNA demethylase and the interaction of Nrf2 with p53 in human colon cancer cells. Exp Ther Med 51: 40, 2019.

53. Zuo Q, Wu R, Xiao X, Yang C, Yang Y, Wang C, Lin L and Kong AN: The dietary flavone luteolin epigenetically activates the Nrf2 pathway and blocks cell transformation in human colorectal cancer HCT116 cells. J Cell Biochem 119: 9573-9582, 2018.

This work is licensed under a Creative Commons Attribution-NonCommercial-NoDerivatives 4.0 International (CC BY-NC-ND 4.0) License. 